\title{
Biocontrol potential of extracellular proteins from Xenorhabdus nematophilus on dengue vectors and the enhancement by response surface methodology
}

\author{
Vani Chandrapragasam*, Anu Jacob, J. Christina Lydia Jayachandran \\ Department of Biotechnology, Karunya Institute of Technology and Sciences, Coimbatore, India.
}

\begin{tabular}{l}
\hline ARTICLE INFO \\
\hline Received on: $03 / 08 / 2018$ \\
Accepted on: $25 / 10 / 2018$ \\
Available online: $30 / 11 / 2018$
\end{tabular}

\section{Key words:}

Xenorhabdus nematophilus, extracellular proteins, dengue vector.

\begin{abstract}
Dengue fever is a prevalent and rapidly spreading disease. It is best controlled by controlling its vectors. Aedes aegypti and Aedes albopictus are the primary and secondary worldwide vectors, respectively, which are bred in peridomestic man-made water containers. Biological control is the most effective and sustainable method as there is no resurgence effect and does not harm humans. Our study includes the use of extracellular proteins of Xenorhabdus nematophilus, a Gram-negative bacterium widely used as biocontrol agents belonging to the family Enterobacteriaceae. The mortality rates of fourth instar larvae A. aegypti when treated with $250 \mu \mathrm{g}$ of extracellular proteins of X. nematophilus, recorded to be $40 \%$ after 72 hours of exposure. The rate of mortality was observed minimum even at higher concentration. The optimization of the medium through response surface methodology showed that there was an increase in the production of extracellular proteins. These proteins played a very important role in the control of A. aegypti. The maximum rate of mortality was recorded to be $92 \%$ when treated with $200 \mu \mathrm{g}$ of extracellular proteins within 48 hours of treatment. Our research proved that the media optimization enhanced the production of extracellular proteins in the $X$. nematophilus and it can be used as a biocontrol agent for the control of dengue vector.
\end{abstract}

\section{INTRODUCTION}

Dengue fever is caused by any of the five serotypes' (DENV 1, 2, 3, 4, and 5) of dengue virus belonging to the family Flaviviridae and transmitted mainly by the insect vector Aedes aegypti, of Culicidae family. It is an arboviral disease with high mortality rates in humans. An approximate of 50 million infections has been estimated, and more than 20,000 deaths occur each year. Though the disease dominates in the tropical areas of the world, it is not completely restricted to those regions, and hence any region infested with the Aedes spp. can lead to the disease as well. Vaccines are not available in the market, and most of them are in the clinical trial phase. If the virus cannot be targeted, then the vector has to be targeted, which calls for physical, chemical,

\footnotetext{
*Corresponding Author

Vani Chandrapragasam, Department of Biotechnology, Karunya Institute of Technology and Sciences, Coimbatore, India.

E-mail:vanimurthi@gmail.com
}

and biological methods of mosquito control (Huang et al., 2017). A novel vaccine for dengue fever has been approved in three countries, but it is not yet commercially available (Dans et al., 2018). As there is no potent drug available against these arboviral diseases, mosquito vector control is an effective measure for the control of dengue fever (Chandran and Azeez, 2015). Various types of control methods were practiced for the control of $A$. aegypti which include repellents and chemical insecticides like Organophospates, such as diflubenzuron and methoprene, etc. (Seccacini et al., 2008). The continuous usage of these insecticides increases resistance in the mosquitoes; hence, there is a need for developing alternative strategies for the control.

Xenorhabdus nematophilus, a Gram-negative bacterium, belonging to the family Enterobacteriaceae. They are symbiotically associated with the entomopathogenic nematodes (EPN) Heterorhabditis and Steinernema species. The EPNs are widely used as biocontrol agents for the control of various crops pests. The bacteria are carried as symbionts in the gut tract (often in a specialized vesicle of the entomopathogenic nematode). The 
foraging nematodes locate the prey insect pests and penetrate to the hemolymph, acting as vectors for the injection of their symbiotic bacteria. These bacteria do not kill the insects if ingested but do so quickly if they are introduced to the hemolymph, either via nematode infection or via syringe injection of laboratory cultures. Once into the hemolymph, the bacteria grow rapidly to produce a variety of extracellular proteins which plays a major role as virulent factors and kills the pests (Walia et al., 2011). This study includes the biological control of $A$. aegypti larvae using extracellular proteins from $X$. nematophilus and the enhancement of proteins by response surface methodology (RSM).

\section{METHODOLOGY}

\section{Culture conditions of $X$. nematophilus}

Xenorhabdus nematophilus (MTCC No 4691 Microbial Type Culture Collection, Gene Bank, Institute of Microbial Technology, Chandigarh, India) was procured. The culture was inoculated in Luria Bertani (LB) broth and yeast starch glucose broth. After incubation for 24 hours at $28^{\circ} \mathrm{C}$, bacterial colonies which were developed was further streaked onto nutrient bromothymol agar medium (NBTA) $(0.025 \%$ bromothymol blue, $0.004 \%$ triphenyl tetrazolium chloride) and was incubated for 24 hours at $28^{\circ} \mathrm{C}$. Pre inoculum cultures were raised in $100-\mathrm{ml}$ flask containing $15-\mathrm{ml}$ media and were incubated at 24 hours at $28^{\circ} \mathrm{C}$ in a rotary shaker at $150 \mathrm{rpm}$. For inoculums preparation, pre inoculum cultures transferred aseptically to $250-\mathrm{ml}$ shake flask containing 100-ml nutrient broth medium (Khandelwal and Bhatnagar, 2003).

\section{Growth of $X$. nematophilus in different media composition}

Xenorhabdus nematophilus was grown in different semisynthetic media (Table 1) to compare the growth. A final $\mathrm{pH}$ of $7.20 \pm 0.02$ was adjusted and media was sterilized at $121^{\circ} \mathrm{C}$ for 20 minutes. Inoculum of $5 \%$ was added to $50 \mathrm{ml}$ of each media in 250 $\mathrm{ml}$ conical flask and was incubated at $28^{\circ} \mathrm{C}$ for 72 hours at $150 \mathrm{rpm}$.

\section{Estimation of biomass}

About $10 \mathrm{ml}$ of culture was centrifuged at $8,000 \mathrm{rpm}$ for 20 minutes. The supernatant obtained after centrifugation was stored at $4^{\circ} \mathrm{C}$ for protein estimation, while the pellet containing cells were dried at $70^{\circ} \mathrm{C}$ until it reached a constant weight (Ahmad et al., 2013).

\section{Screening of medium components by Plackett Burman design}

Plackett Burman design can be used for screening various medium components and it also examines $(n-1)$ variables in at least " $n$ " number of experiments. (Stowe and Mayer, 1966). In each of the experimental run, the frequency of every level of a variable is constant and the number of high and low variables is equal. While determining the effect of a particular variable, the effects of changing the other variables cancel out. The main effect is calculated from the difference of the average observations at high $(\mathrm{H})$ level and average observations at the low level (L) of each factor. In the case of $X$. nematophilus, 11 factors including two dummy variables were screened in 12 combinations (Table 2) and all trials were performed in duplicate and average of observation was used as a response of design (Fattah et al., 2002).
Table 1. Composition of semi-synthetic media (Fang et al., 2010; Wang et al., 2008).

\begin{tabular}{|c|c|}
\hline Media & Composition (g/l) \\
\hline \multirow[t]{5}{*}{ TSB } & Tryptone -17.00 \\
\hline & Soy peptone -3.00 \\
\hline & Glucose -2.50 \\
\hline & $\mathrm{NaCl}-5.00$ \\
\hline & $\mathrm{K}_{2} \mathrm{HPO}_{4}-2.50$ \\
\hline \multirow[t]{7}{*}{ WYH } & Glucose -6.13 \\
\hline & Peptone -21.29 \\
\hline & $\mathrm{MgSO}_{4} \cdot 7 \mathrm{H}_{2} \mathrm{O}-1.50$ \\
\hline & $\left(\mathrm{NH}_{4}\right)_{2} \mathrm{SO}_{4}-2.46$ \\
\hline & $\mathrm{KH}_{2} \mathrm{PO}_{4}-0.86$ \\
\hline & $\mathrm{K}_{2} \mathrm{HPO}_{4}-1.11$ \\
\hline & $\mathrm{Na}_{2} \mathrm{SO}_{4}-1.72$ \\
\hline \multirow[t]{4}{*}{ Nutrient Broth } & Beef extract-1 \\
\hline & Yeast extract-2 \\
\hline & Peptone -5 \\
\hline & $\mathrm{NaCl}-5$ \\
\hline Modified nutrient broth & $\mathrm{NB}+\mathrm{NaCl}-5.00$ \\
\hline \multirow[t]{3}{*}{ LB } & Tryptone- -10.00 \\
\hline & Yeast extract- -5.00 \\
\hline & $\mathrm{NaCl}-10.00$ \\
\hline \multirow[t]{7}{*}{ YSG } & Glycerol— -5.00 \\
\hline & Yeast extract- -5.00 \\
\hline & $1 \mathrm{M}-\mathrm{MgSO}_{4}-5 \mathrm{ml}$ \\
\hline & $\left(\mathrm{NH}_{4}\right)_{2} \mathrm{SO}_{4}-2.00$ \\
\hline & $1 \mathrm{M}-\mathrm{KH}_{2} \mathrm{OP}_{4}-5 \mathrm{ml}$ \\
\hline & $1 \mathrm{M}-\mathrm{K}_{2} \mathrm{HOP}_{4}-5 \mathrm{ml}$ \\
\hline & $1 \mathrm{M}-\mathrm{Na}_{2} \mathrm{SO}_{4}-10 \mathrm{ml}$ \\
\hline \multirow[t]{4}{*}{ YS } & Yeast extract- -5.00 \\
\hline & $\left(\mathrm{NH}_{4}\right)_{2} \mathrm{SO}_{4}-5.00$ \\
\hline & $\mathrm{MgSO}_{4} \cdot 7 \mathrm{H}_{2} \mathrm{O}-0.20$ \\
\hline & $\mathrm{KH}_{2} \mathrm{PO}_{4}-0.50$ \\
\hline
\end{tabular}

Table 2. Plackett-Burman experimental design.

\begin{tabular}{ccccccccccccc}
\hline Exp Run & A & B & C & D & E & F & G & H & J & K & L & Protein(g/l) \\
\hline 1 & H & L & L & L & H & H & H & L & H & H & L & 933.00 \\
2 & L & H & H & L & H & L & L & L & H & H & H & $1,066.47$ \\
3 & L & L & L & L & L & L & L & L & L & L & L & 904.17 \\
4 & H & H & H & L & H & H & L & H & L & L & L & 932.00 \\
5 & L & H & H & H & L & H & H & L & H & L & L & $1,043.55$ \\
6 & L & L & H & H & H & L & H & H & L & H & L & $1,466.67$ \\
7 & L & L & L & H & H & H & L & H & H & L & H & 985.42 \\
8 & H & L & H & L & L & L & H & H & H & L & H & 972.72 \\
9 & H & L & H & H & L & H & L & L & L & H & H & $1,475.75$ \\
10 & H & H & L & H & L & L & L & H & H & H & L & 968.33 \\
11 & H & H & L & H & H & L & H & L & L & L & H & 800.55 \\
12 & L & H & L & L & L & H & H & H & L & H & H & 915.00 \\
\hline
\end{tabular}

Where uncoded values in $\mathrm{g} / \mathrm{l}(\mathrm{H}, \mathrm{L})$; A-glucose $(5,1)$, B - peptone $(12.5,5)$, C-tryptone $(12.5,5), \mathrm{D}-\mathrm{NaCl}(4,0.5), \mathrm{E}-\mathrm{MgS} .7 \mathrm{O}(1,0.05), \mathrm{F}-\mathrm{KPHP}(4,0.05), \mathrm{H}$-yeast extract $(1.5,0.25), \mathrm{I} \longrightarrow\left(\mathrm{NS}, \mathrm{J}\right.$-agitation $(150 \mathrm{rpm})$, and $\mathrm{K}$-temperature $\left(28^{\circ} \mathrm{C}\right)$ 
Table 3. RSM experiment design.

\begin{tabular}{cccccc}
\hline Experiment & Glucose & Peptone & $\mathbf{N a C l}$ & Predicted response protein (g/l) & Experimental response protein (g/l) \\
\hline 1 & -1 & 0 & -1 & $1,220.1$ & $1,291.667$ \\
2 & -1 & -1 & 0 & $1,076.8$ & $1,041.667$ \\
3 & -1 & 0 & 1 & $1,238.3$ & $1,260.417$ \\
4 & 1 & 0 & -1 & $1,688.9$ & $1,666.667$ \\
5 & 0 & -1 & 1 & 882.8 & 895.8333 \\
6 & 1 & 1 & 0 & $1,183.6$ & $1,218.75$ \\
7 & 0 & -1 & -1 & 1,099 & $1,062.5$ \\
8 & 0 & 0 & 0 & $1,429.4$ & $1,645.833$ \\
9 & 1 & 0 & 1 & $1,279.9$ & $1,208.333$ \\
10 & 0 & 1 & -1 & 929.8 & 916.6667 \\
11 & 0 & 1 & 1 & 755.2 & 791.6667 \\
12 & 0 & 0 & 0 & $1,429.4$ & $1,437.5$ \\
13 & 0 & 0 & 0 & $1,429.4$ & $1,395.833$ \\
14 & 1 & -1 & 0 & $1,462.2$ & $1,520.833$ \\
15 & -1 & 1 & 0 & $1,058.6$ & 1,000 \\
\hline
\end{tabular}

Where uncoded values $(-1,+1)$ in $\mathrm{g} / \mathrm{l}$ : glucose $(5,20)$, peptone $(5,20)$, and $\mathrm{NaCl}(1,10)$.

\section{Response surface methodology}

The significant variables obtained from screening experiments were optimized using RSM. A three-factor and a three-level $(-1,0$, and +1$)$ Box Behnken design (BBD) consisting of 15 experimental runs was used (Table 3 ). The experiments were carried out in duplicates and average values of the response are taken. The analysis of the responses was done with Minitab v18 (Minitab Inc., State College, PA). A quadratic model is obtained to study the interaction between the variables. The BBD is a spherical design and also have fewer runs as compared with other three-level factorial designs (Box and Behnken, 1960; Ferreira et al., 2007; Khuri and Mukhopadhyay, 2010; Myers et al., 2009).

\section{Estimation of extracellular protein from $X$. nematophilus}

The supernatant of culture was precipitated in $70 \%$ ammonium sulfate using a magnetic stirrer in ice-cold condition and kept overnight at $4{ }^{\circ} \mathrm{C}$. After 24 hours, the precipitated supernatant was centrifuged at $10,000 \mathrm{rpm}$ for 30 minutes at $4^{\circ} \mathrm{C}$. The pellet was suspended in $0.1 \mathrm{M}$ Tris buffer $(\mathrm{pH} 7.5)$ and transferred into a dialysis bag. The buffer was changed for two-three times. The protein thus obtained was transferred into Eppendorf tubes and stored at $-20^{\circ} \mathrm{C}$ (Ramasamy et al., 2008). Protein content was estimated by Lowry's et al. (1961) method.

\section{Mosquito culture}

The mosquito larvae of $A$. aegypti were collected and identified from the National Center for Disease and Control, Mettupalayam. The eggs of $A$. aegypti were collected and kept in the tray in the laboratory at room condition and allowed to hatch within 2 days after hatching the fourth instar larvae were used for the present study.

Larvicidal activity on A. aegypti using extracellular proteins of X. nematophilus

Different concentrations of 50, 100,200,800, and 1,000 $\mu \mathrm{g}$ of extracellular proteins of 24 and 48 hours culture supernatant were treated against fourth instar larvae of $A$. aegypti. The concentrations of protein in $\mu \mathrm{g} / \mathrm{ml}$ were dissolved in $25 \mathrm{ml}$ of chlorine-free tap water and five larvae were introduced per treatment. Each treatment was repeated three times for replication (Brammacharry and Paily, 2012). The rate of mortality was recorded for every 24,48 , and 72 hours by using Abbott's formula (1925).

$$
\text { Percentage of mortality }=\left(\frac{\text { Number of larva dead }}{\text { number of larvae }}\right) \times 100
$$

\section{Statistical analysis}

All the values are expressed as the mean \pm standard deviation (SD). All the experiments were performed in triplicates. Statistical analyses were performed with graph pad Prism 4 software; using two-way analysis of variance (ANOVA) followed by Turkey Kramer multiple comparison tests. The significance was set at $p<0.05$.

\section{RESULT AND DISCUSSION}

\section{Biomass of X. nematophilus cultured in different media}

The effects of different medium (Table 1) on the growth of $X$. nematophilus are represented in Figure 1. TSB medium gave maximum growth when compared with the other media and it was employed for further optimizations. TSB has been reported for high biomass and antibiotic productivity in Xenorhabdus by Fang et al. (2010).

Larvicidal activity of the extracellular proteins of $X$. nematophilus cultured in TSB medium against A. aegypti fourth instar larvae

Figure 2 represents the rate of mortality of $A$. aegypti larvae treated with extracellular proteins from 24 hours culture supernatant of $X$. nematophilus. The rate of mortality was recorded for every 24,48 , and 72 hours of treatment. It was observed that the mortality rate was recorded $0 \%$ in the treatments with 50 , 100 , and $150 \mu \mathrm{g} / \mathrm{ml}$ of extracellular proteins. Maximum rate of mortality was observed to be $40.0 \%$ at 72 hours of treatment. 


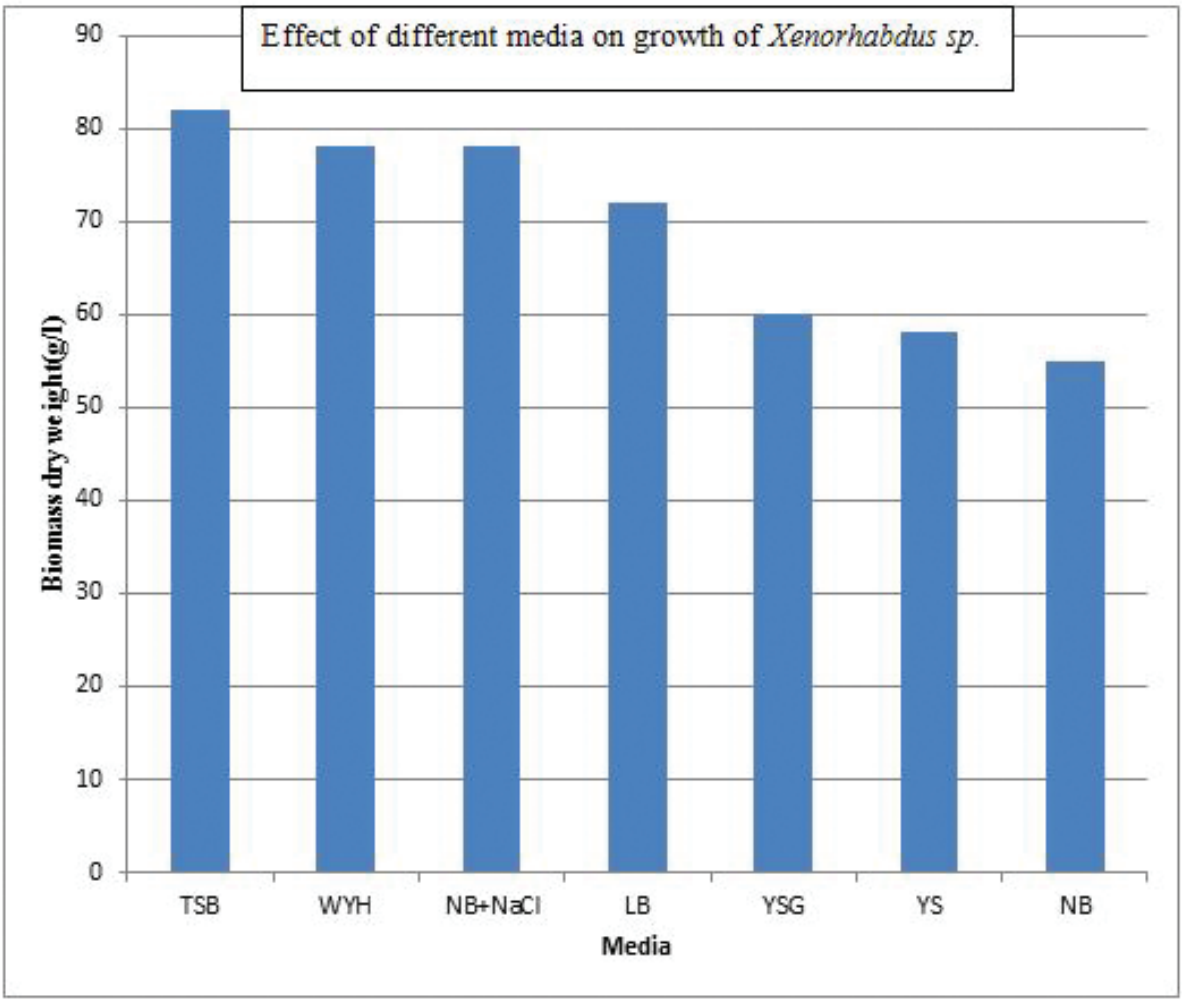

Figure 1. Effect of different media on the growth of Xenorhabdus sp.

Effect of 24 hrs culture supernatant against Aedes agypti before media optimization

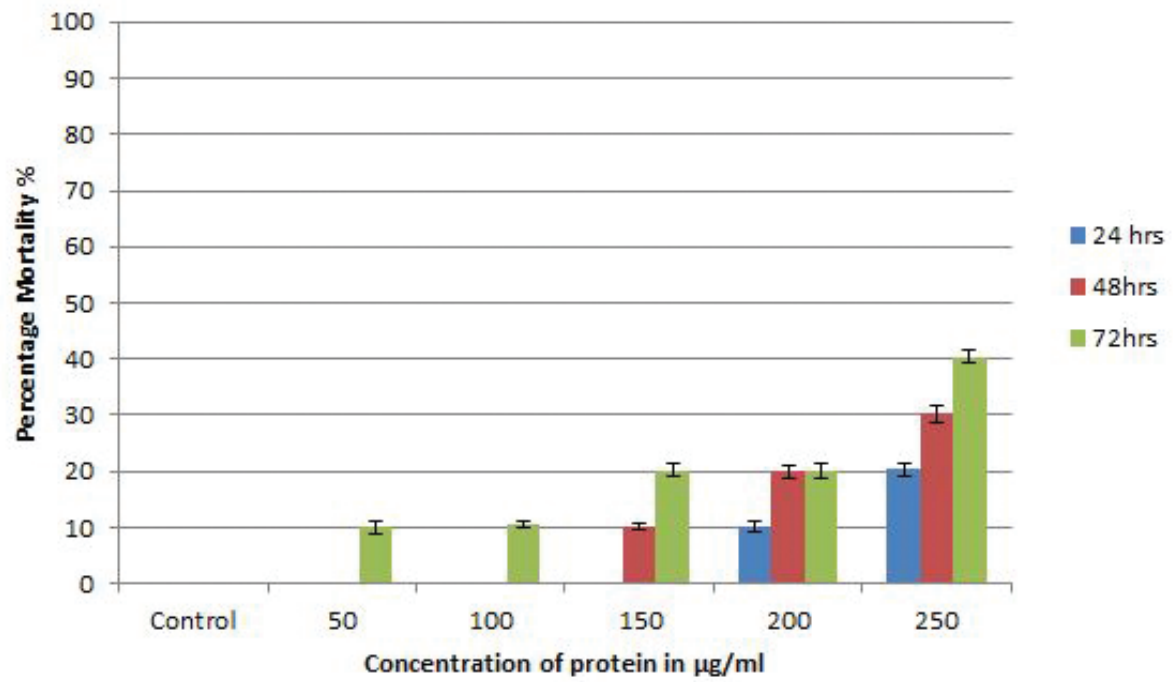

Figure 2. Effect of 24 hours supernatant against A. aegypti before media optimization.

Figure 3 represents the mortality rate of fourth instar larvae of $A$. aegypti treated with extracellular proteins from 48-hour culture supernatant. Maximum mortality rate was recorded to be $20 \%$ when treated with $200 \mu \mathrm{g} / \mathrm{ml}$ of extracellular proteins after 24 hours of exposure. Minimum mortality of $13.2 \%$ was recorded after 24 and 48 hours of exposure when treated with 50, 150, and $250 \mu \mathrm{g} / \mathrm{ml}$ of extracellular proteins. However, there was no substantial mortality observed after 72 hours of exposure. Considerable mortality rate was not observed in $A$. aegypti fourth instar larvae treated with extracellular proteins of $X$. nematophilus. This result was not on a par with the result of Forst et.al. (1997) who reported that the Xenorhabdus spp. killed $90 \%$ of the larvae 


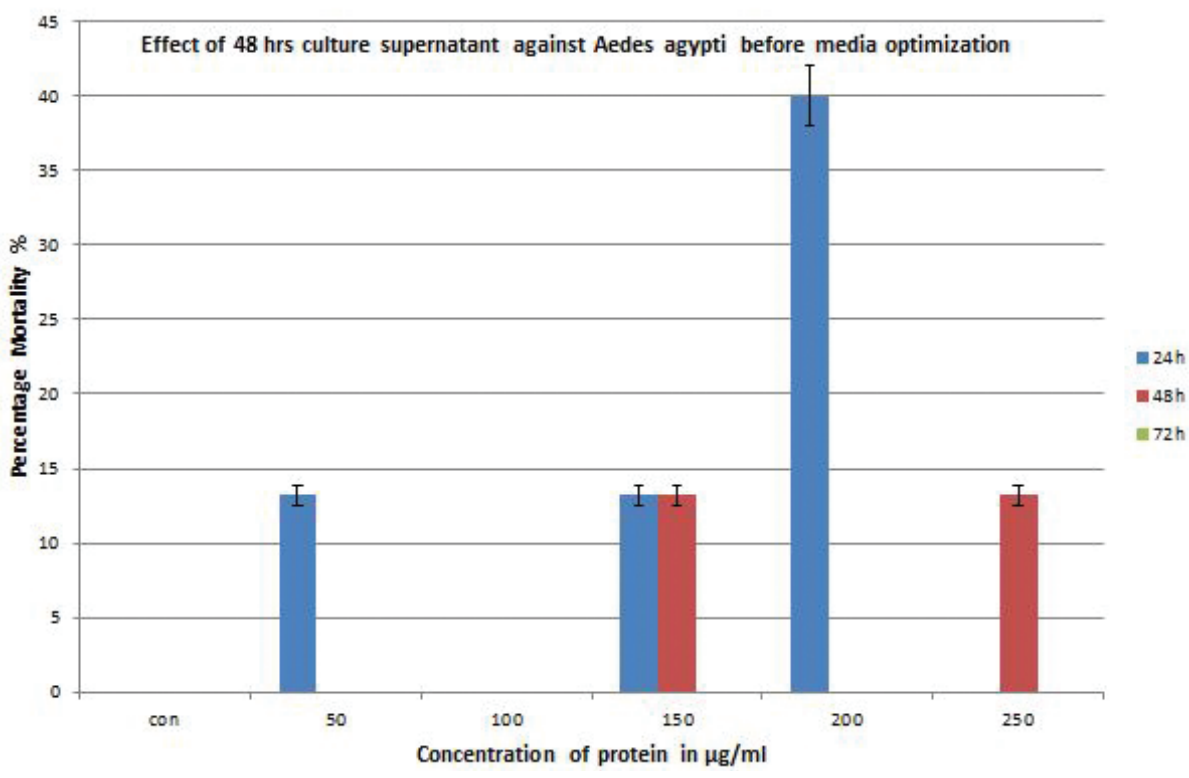

Figure 3. Effect of 48 hours supernatant against A. aegypti before media optimization.

of Manduca sexta which is a pest of tobacco. The lower mortality rate may be due to the composition of the media which has led to the lesser production and virulence of extracellular proteins. From the results it was observed that the biomass production of $X$. nematophilus in TSB medium was recorded as the highest ( 82 $\mathrm{g} / \mathrm{l})$; however, the larvicidal activity of extracellular proteins was minimal $(40.0 \%)$ in TSB medium. The larvicidal activity of the extracellular proteins against $A$. aegypti was recorded minimum of $40.0 \%$. Hence, the observations recommend the optimization of TSB medium to enhance the protein production thereby the efficiency of larvicidal activity of the $X$. nematophilus.

\section{Effect of different medium components on the extracellular protein production}

Standard methods proposed by Plackett-Burman were employed for experimental data analysis (Plackett and Burman, 1946). The effect of each variable was calculated with the following equation:

$$
\mathrm{Exi}=2\left(\frac{\sum \mathrm{Hxi}-\sum \mathrm{Lxi}}{N}\right)
$$

Where Exi is the effect (concentration) of the tested variable, Hxi and Lxi are the protein yield at the high and low level, respectively, of the same variable, and $N$ is the number of trials. The positive effect implies that the impact of the variable on protein is at high concentration while negative effect implies that the impact on protein is greater at low concentration.

Mean squares of each variable (the variance of effect):

$$
\mathrm{Vxi}=\frac{\left(\sum \mathrm{Hxi}-\sum \mathrm{Lxi}\right)^{2}}{N}
$$

The experimental error: $R=\sum \mathrm{Vxd} / n$ is calculated by taking an average of mean squares of dummy variables

$F$ test is used to identify the factors with larger: $F=\mathrm{Vxi} / R$, where $R$ is the experimental error. $\mathrm{Vxd}$ is the mean
Table 4. Influence of variables on protein production.

\begin{tabular}{lcc}
\hline Factors & Effect & $\boldsymbol{F}$ test \\
\hline Peptone & 203.4983 & 19.87 \\
$\mathrm{NaCl}$ & 203.4017 & 19.85 \\
$\mathrm{Glucose}$ & 168.305 & 13.59 \\
Tryptone & -150.04 & 10.80 \\
$\mathrm{KH}_{2} \mathrm{PO}_{4}$ & -139.90 & 9.391 \\
Yeast extract & 76.87 & 2.835 \\
Agitation & 51.58 & 1.276 \\
Temperature & 38.81 & 0.723 \\
$\left(\mathrm{NH}_{4}\right)_{2} \mathrm{SO}_{4}$ & -37.54 & 0.676 \\
$\mathrm{~K}_{2} \mathrm{HPO}_{4}$ & 35.04 & 0.589 \\
$\mathrm{MgSO}_{4}$ & 26.13 & 0.327 \\
\hline
\end{tabular}

square of dummy variable; Vxi is the mean square of variable and $n$ is the number of dummy variables. Table 4 summarizes the effect and $F$ test value for all the variables.

Peptone, $\mathrm{NaCl}$, and glucose have shown high $F$ value and hence very significant for the protein production. The Pareto chart (Fig. 4) generated also displays the significant factor for protein yield. Variables like peptone, $\mathrm{NaCl}$, glucose, yeast extract, $\mathrm{K}_{2} \mathrm{HPO}_{4}$, and $\mathrm{MgSO}_{4} 7 \mathrm{H}_{2} \mathrm{O}$ have shown positive effect while other variables like tryptone, $\mathrm{KH}_{2} \mathrm{PO}_{4}$, and $\left(\mathrm{NH}_{4}\right)_{2} \mathrm{SO}_{4}$ have a negative effect on the protein production.

\section{Optimization of medium by RSM}

Three variables which included glucose, peptone, and $\mathrm{NaCl}$ were examined for their optimum combination using BBD and the actual responses and the responses predicted by the model are compared (Table 2). ANOVA was carried out for responses (Table 5). A second-order polynomial equation was developed for the experimental data by applying multiple regression analysis.

Protein $=1,429.4+127.6$ Glucose -74.2 Peptone -97.7 $\mathrm{NaCl}+103.0$ Glucose * Glucose -337.1 Peptone * Peptone -175.6 


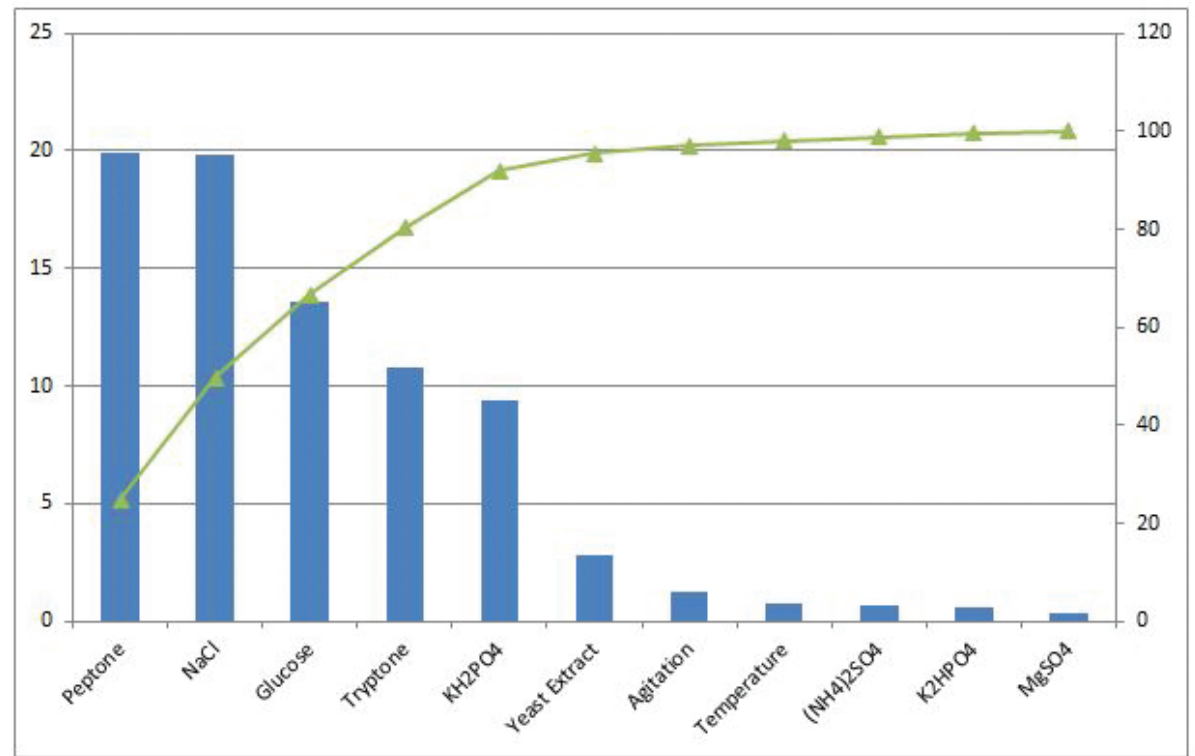

Figure 4. Pareto chart of effects on extracellular protein production.

Table 5. ANOVA for experimental results.

\begin{tabular}{lccccc}
\hline Source & DF & Adj SS & Adj MS & $\boldsymbol{F}$-Value & $\boldsymbol{p}$-Value \\
\hline Model & 9 & 889,216 & 98,802 & 19.79 & 0.002 \\
Linear & 3 & 250,625 & 83,542 & 16.74 & 0.005 \\
Glucose & 1 & 130,262 & 130,262 & 26.10 & 0.004 \\
Peptone & 1 & 44,068 & 44,068 & 8.83 & 0.031 \\
$\mathrm{NaCl}$ & 1 & 76,294 & 76,294 & 15.29 & 0.011 \\
Square & 3 & 575,602 & 191,867 & 38.44 & 0.001 \\
Glucose*Glucose & 1 & 39,178 & 39,178 & 7.85 & 0.038 \\
Peptone*Peptone & 1 & 419,569 & 419,569 & 84.06 & 0.000 \\
NaCl*NaCl & 1 & 113,901 & 113,901 & 22.82 & 0.005 \\
2-way interaction & 3 & 62,990 & 20,997 & 4.21 & 0.078 \\
Glucose*Peptone & 1 & 16,954 & 16,954 & 3.40 & 0.125 \\
Glucose*NaCl & 1 & 45,601 & 45,601 & 9.14 & 0.029 \\
Peptone*NaCl & 1 & 434 & 434 & 0.09 & 0.780 \\
Error & 5 & 24,957 & 4,991 & & \\
Lack-of-Fit & 3 & 23,574 & 7,858 & 11.36 & 0.082 \\
Pure error & 2 & 1,384 & 692 & & \\
Total & 14 & 914,173 & & & \\
\hline
\end{tabular}

$\mathrm{NaCl} * \mathrm{NaCl}-65.1$ Glucose $*$ Peptone -106.8 Glucose $* \mathrm{NaCl}+$ 10.4 Peptone * $\mathrm{NaCl}$

From the ANOVA, the model was highly significant with a very low $p$-value of 0.002 . Lack of fit of the model is insignificant as it was $>0.05$ (Table 5). The value of the coefficient of determination $(\mathrm{R} 2=97.27)$ suggested that the model is a good fit. The adjusted R2 is $92.36 \%$ which implies that the insignificant terms are negligible as it is close to R2. Among the parameters, all the three variables have a significant impact on protein production as its $p<0.05$. The maximum interaction occurred between glucose and $\mathrm{NaCl}$ with the $p$-value 0.02 . The 3-D plots (Fig. 5a-c) represent a visual interpretation of the interaction between two factors. From Figure 5a, it is obvious that increasing glucose and peptone concentration increased protein and further increase reduced the protein production. Figure $5 \mathrm{~b}$ and $\mathrm{c}$ showed a similar effect on protein and the factors.

The optimal values for the factors were calculated using the response optimizer with the goal of maximizing protein. The optimum protein production conditions were predicted to be with a concentration of glucose $-10 \mathrm{~g} / 1$, peptone $-16 \mathrm{~g} / \mathrm{l}$, and $\mathrm{NaCl}-$ $2.4 \mathrm{~g} / \mathrm{l}$ using response optimizer and response surface plots.

The experimental validation of the model was attempted with the optimized media constituents as glucose-10 g/l, peptone $-16 \mathrm{~g} / \mathrm{l}$, and $\mathrm{NaCl}-2.4 \mathrm{~g} / 1$ and observed that $1,700 \mathrm{~g} / 1$ extracellular protein was produced and is very close to the expected observation.

Kumar et al. (2014) reported significant role of soya peptone $4.9 \mathrm{~g} / \mathrm{l}$ and $\mathrm{NaCl} 1.45$ for the production of fibrinolytic alkaline metalloproteases $(66.31 \%$ increase) from Xenorhabdus indica KB-3; however, other major components in media include carbon sources (tryptone - 5.71, dextrose-1.45,) and metal ion dipotassium phosphate $-0.47 \mathrm{~g} / \mathrm{l}$. Cations in the media induce the secretion of enzyme and improve the thermostability of enzymes. There are reports on glucose as the optimal carbon source for the production of secondary metabolites with antimicrobial activity in $X$. nematophila (Wang et al., 2008; Yang et al., 2001)

Larvicidal activity of extracellular proteins of X. nematophilus cultured in optimized media against A. aegypti fourth instar larvae

In 24-hour culture supernatant (Fig. 6), the rate of mortality of $A$. aegypti fourth instar larvae was recorded maximum of $92 \%$ and $93.2 \%$ at 72 hours of treatment with 200 and $250 \mu \mathrm{g} / \mathrm{ml}$ extracellular proteins, respectively. The minimum mortality rate of $46.6 \%$ was observed in the larvae when treated with $50 \mu \mathrm{g} / \mathrm{ml}$ of extracellular protein after 48 hours of treatment. Whereas in 48-hour culture supernatant (Fig. 7), maximum mortality rate of $53.2 \%$ was recorded after 72 hours of exposure when treated with $150 \mu \mathrm{g} / \mathrm{ml}$ of extracellular protein and a minimum mortality 


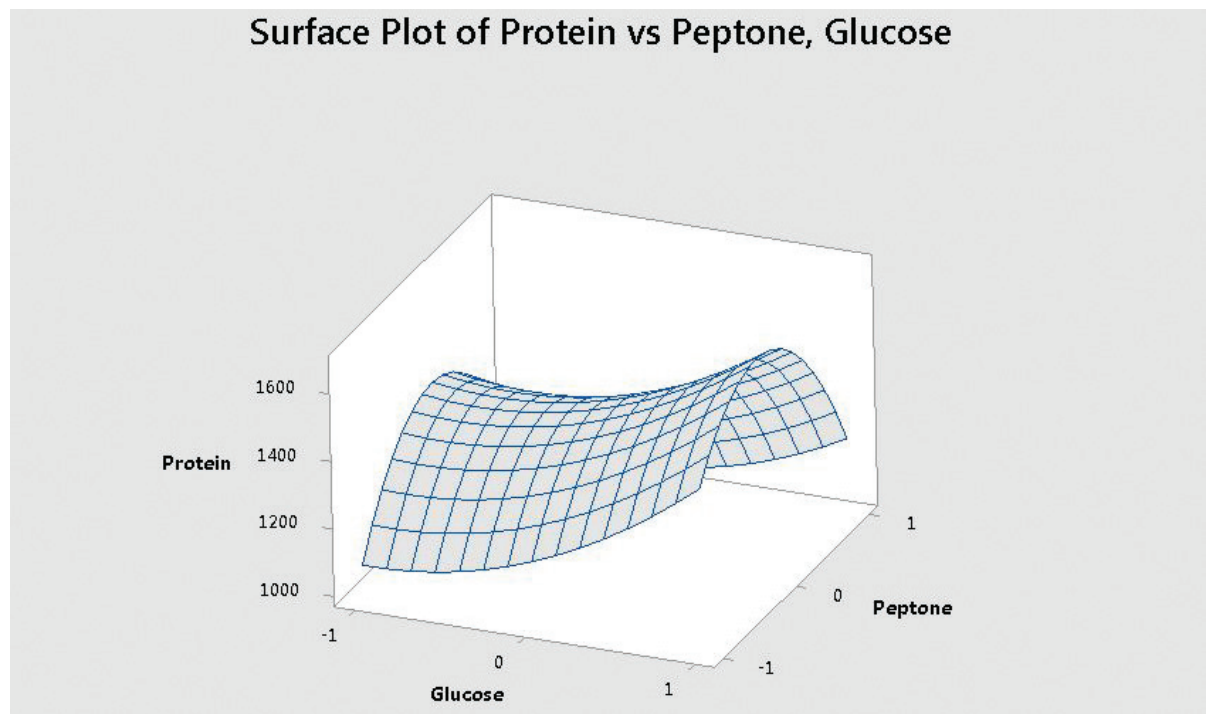

\section{Surface Plot of Protein vs $\mathrm{NaCl}$, Glucose}

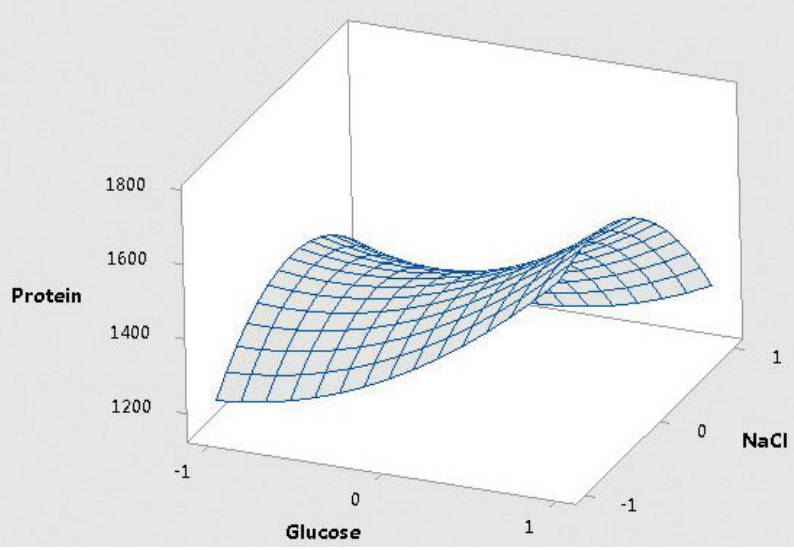

Surface Plot of Protein vs $\mathrm{NaCl}$, Peptone

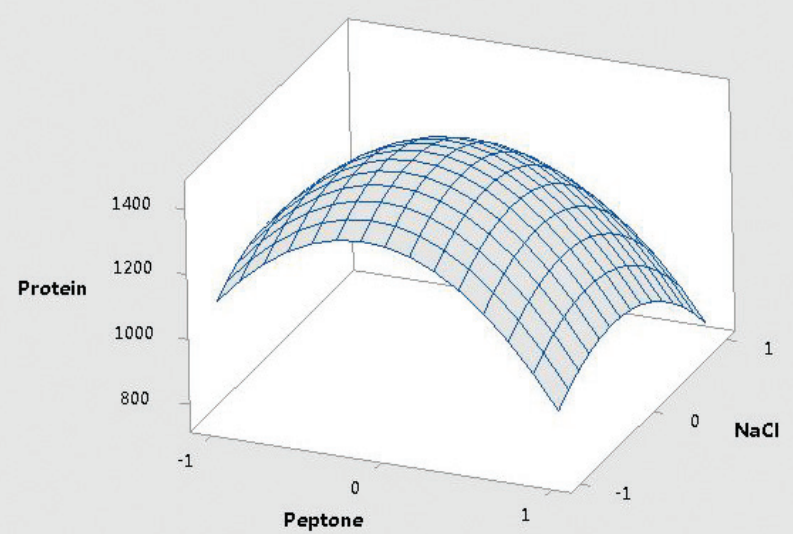

Figure 5. (a) Surface plot of protein $(\mathrm{g} / \mathrm{l})$ versus glucose ( $\mathrm{g} / \mathrm{l})$ versus peptone $(\mathrm{g} / \mathrm{l})$. (b) Surface plot of protein $(\mathrm{g} / \mathrm{l})$ versus glucose $(\mathrm{g} / \mathrm{l})$ versus $\mathrm{NaCl}(\mathrm{g} / \mathrm{l})$. (c) Surface plot of protein $(\mathrm{g} / \mathrm{l})$ versus $\mathrm{NaCl}(\mathrm{g} / \mathrm{l})$ versus peptone $(\mathrm{g} / \mathrm{l})$. 
Effect of 24 hrs culture supernatant against Aedes agypti after media optimization

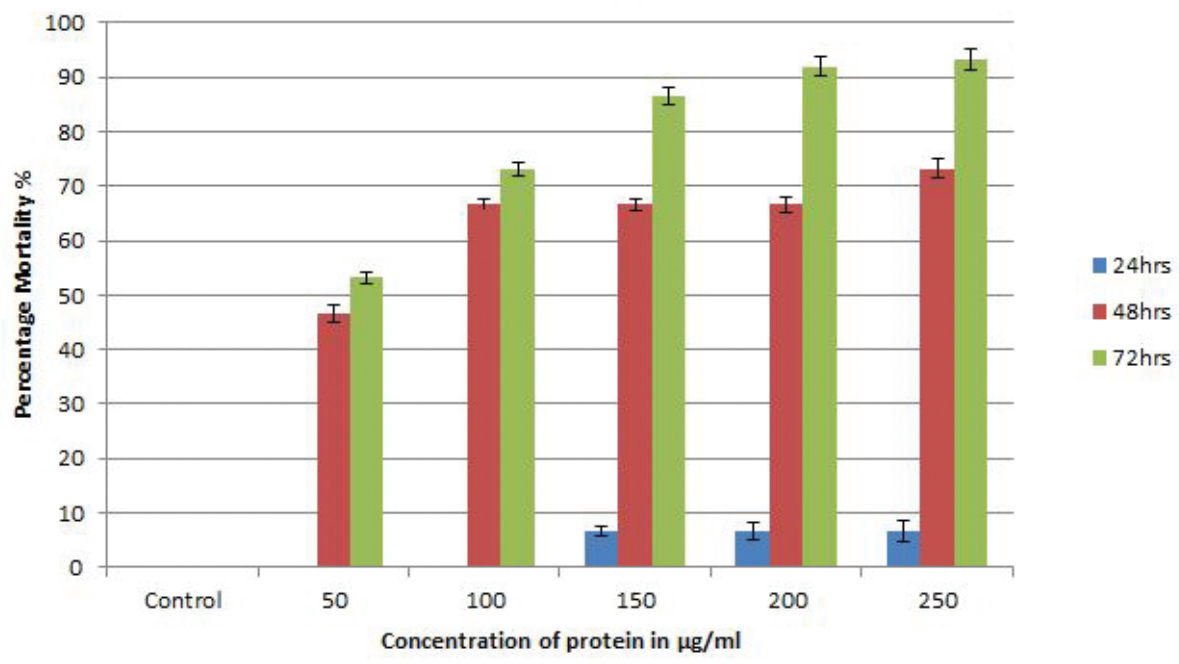

Figure 6. Effect of 24 hours culture supernatant of X. nematophilus against A. aegypti fourth instar larvae after media optimization.

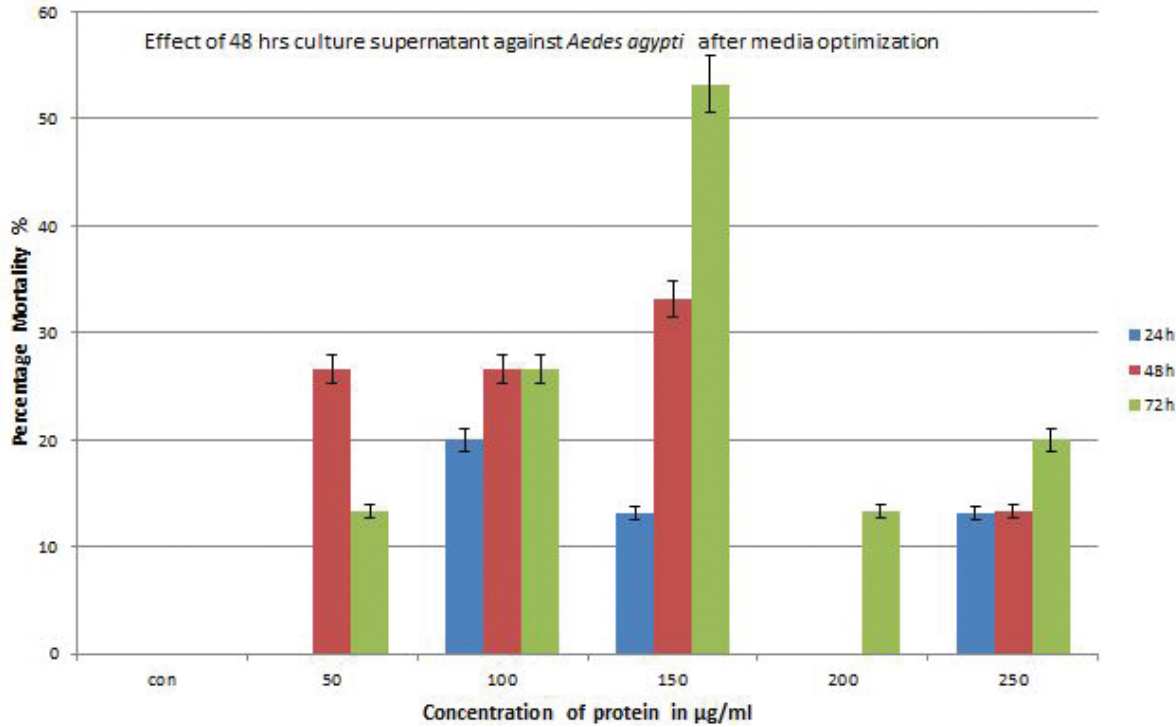

Figure 7. Effect of 48 hours culture supernatant of X. nematophilus against A. aegypti fourth instar larvae after media optimization.

$(13.2 \%)$ was recorded after 24 hours of exposure with 150 and $250 \mu \mathrm{g} / \mathrm{ml}$ of extracellular proteins treated.

After the media optimization, it was interesting to note that the rate of mortality was observed to be $53.2 \%$ even at a lower $50 \mu \mathrm{g} / \mathrm{ml}$ concentration of extracellular proteins of $X$. nematophilus (24-hour culture supernatant) treated against $A$. aegypti at 72 hours of treatment. Our results proved that the mortality rate was higher when compared with the results of Fukruksa et al. (2017). They reported that Xenorhabdus stockiae recorded 60\% mortality after 96 hours of treatment in A. aegypti larvae. Cannibalism was observed when the larvae were exposed to suspensions of $X$. nematophila and lead to a maximum of $72 \%$ mortality in 96 hours of incubation (Silva et al., 2013). Owuama (2001) reported that proteinases resulted in histological lesions leading to the death of the insect. This higher mortality rate obtained in $A$. aegypti larvae was due to the improved protein production after media optimization. The optimization parameters glucose, peptone, and $\mathrm{NaCl}$ involved in the production of extracellular proteins in the medium.

This may be due to the increased production of lipase, protease, phospholipases, and chitinases in the medium because of the optimization of carbon and nitrogen sources. Our results are in accordance with the previous work of Caldas et al. (2002). They observed that the increased production of extracellular enzymes in the medium involved in the insecticidal properties and it is not harmful to humans. Herbert and Goodrich-Blair (2007) had a similar report that $X$. nematophila controls the insects by inhibiting both at its cellular and humoral immunity and can inhibit the synthesis of antimicrobial peptides. The virulence factors comprising proteases, lipases are responsible in this larvicidal activity. 
Although the 48-hour culture supernatant improved the larvicidal activity, it is not as significant as 24 -hour culture supernatant protein. The extracellular proteins produced by media optimization in Xenorhabdus spp. will be an effective biopesticide for the eradication of dengue vectors. Further, this research can be extended for the identification and characterization of the extracellular proteins.

\section{CONCLUSION}

From the above study, it was interesting to note that media optimization played an important role in the production of extracellular proteins of $X$. nematophilus in the medium which caused $93.2 \%$ mortality in $A$. aegypti fourth instar larvae after 72 hours of treatment. Before optimization, the rate of mortality was $40 \%$ after 72 hours of treatment. This research would pave way for the eradication of dengue vectors for the control of dengue fever. The screening of different variables, responsible for the production of extracellular protein, was carried out with the help of PlackettBurman design and obtained that glucose, peptone, and $\mathrm{NaCl}$ are the major factors which significantly improve the production of extracellular proteins. RSM was followed in the optimization of selected factors and observed that glucose $-10 \mathrm{~g} / 1$, peptone $-16 \mathrm{~g} / \mathrm{l}$, and $\mathrm{NaCl}-2.4 \mathrm{~g} / \mathrm{l}$ can maximize the extracellular protein yield. A two-fold increase in the protein was attained after the media optimization. Further research has to be carried out in the purification of the specific protein with the insecticidal activity and this process can be scaled up to effectively control the dengue vector.

\section{REFERENCES}

Abbot WS. A method of computing the effectiveness of an insecticide. J Econ Entomol, 1925; 18:265-7.

Ahmad R, Al-Shorgani NN, Hamid AA, Yusoff WMW, Daud F. Optimization of medium components using response surface methodology (RSM) for mycelium biomass and exopolysaccharide production by Lentinus squarrosulus. Adv Biosci Biotechnol, 2013; 4:1079-85.

Box GEP, Behnken DW. Some new three level designs for the study of quantitative variables. Techno Metrics, 1960; 2:455-75.

Brammacharry U, Paily K. Chitinase like activity of metabolites of Pseudomonas fluorescens Migula on immature stages of the mosquito, Culex quinquefasciatus (Diptera: Culicidae). Afr J Microbiol Res, 2012; 6:2718-26.

Caldas C, Cherqui A, Pereira A, Simões N. Purification and characterization of an extracellular protease from Xenorhabdus nematophila involved in insect immunosuppression. Appl Environ Microbiol, 2002; 68:1297-304

Chandran R, Azeez PA. Outbreak of dengue in Tamil Nadu, India. Curr Sci India, 2015; 109:171-6.

Dans AL, Dans LF, Lansang MAD, Silvestre MAA, Guyatt GH. Controversy and debate on dengue vaccine series-paper 1: review of a licensed dengue vaccine: inappropriate subgroup analyses and selective reporting may cause harm in mass vaccination programs. J Clin Epidemiol, 2018; 95:137-9.

Fang XL, Feng JT, Zhang WG, Wang YH, Zhang X. Optimization of growth medium and fermentation conditions for improved antibiotic activity of Xenorhabdus nematophila TB using a statistical approach. Afr J Biotechnol, 2010; 9:8068-77.

Fattah AYR, Soliman NA, Gaballa AA, Sary SA, Ei- Diwany AI. Lipase production from novel thermophilic Bacillus sp: application of Plackett Burman design for evaluating culture conditions affecting enzyme formation. Acta Microbiol Pol, 2002; 51:353-66.

Ferreira SLC, Bruns RE, Ferreira HS, Matos GD, David JM, Brandao GC, da Silva EGP, Portugal LA, dos Reis PS, Souza AS, dos Santos WNL. Box-Behnken design: an alternative for the optimization of analytical methods. Analytica Chimica Acta, 2007; 597:179-86.
Forst S, Dowds B, Boemare NE, Stackebrandt E. Xenorhabdus spp. and Photorhabdus spp.: bugs that kill bugs. Annu Rev Microbiol, 1997; $51: 47-72$.

Fukruksa C, Yimthin T, Suwannaroj M, Muangpat $P$, Tandhavanant S, Thanwisai A, Vitta A. Isolation and identification of Xenorhabdus and Photorhabdus bacteria associated with entomopathogenic nematodes and their larvicidal activity against Aedes aegypti. Parasit Vectors, 2017; 10:440.

Herbert EE, Goodrich-Blair H. Friend and foe: the two faces of Xenorhabdus nematophila. Nat Rev Microbiol, 2007; 5:634-46.

Huang YJS, Higgs S, Vanlandingham DL. Biological control strategies for mosquito vectors of arboviruses. Insects, 2017; 8:21.

Khandelwal P, Bhatnagar NB. Insecticidal Activity Associated with the Outer Membrane Vesicles of Xenorhabdus nematophilus. Appl Environ Microbiol, 2003; 69:2032-7.

Khuri AI, Mukhopadhyay S. Response surface methodology. Comput Stat, 2010; 2:128-49.

Kumar P, Singh S, Dutta D, Chaudhuri S, Ganguly S, Nain L. Statistical optimization of media components for production of fibrinolytic alkaline metalloproteases from Xenorhabdus indica KB-3. Biotechnol Res Int, 2014; Article ID 293434:11.

Lowry OH, Rosebrough NJ, Farr AL, Randall RJ. Protein measurement with the Folin phenol reagent. J Biol Chem, 1961; 193:265-75.

Myers RH, Montgomery DC, Anderson-Cook CM. Response surface methodology: process and product optimization using designed experiments. John Wiley \& Sons, New Jersey, 2009.

Owuama CI. Entomopathogenic symbiotic bacteria, Xenorhabdus and Photorhabdus of nematodes. World J Microbiol Biotechnol, 2001; 17:505-15.

Plackett RL, Burman JP. The design of optimum multifactorial. Biometrika, 1946; 33:305-25.

Seccacini E, Lucia A, Harburguer L, Zerba E, Licastro S, Masuh H. Effectiveness of pyriproxyfen and diflubenzuron formulations as larvicide against Aedes aegypti. J Am Mosq Control Assoc, 2008; 24:398-403.

Silva Odd, Prado GR, Silva JLRd,Silva CE, Costa Md, Heermann R. Oral toxicity of Photorhabdus luminescens and Xenorhabdus nematophila (Enterobacteriaceae) against Aedes aegypti (Diptera: Culicidae). Parasitol Res, 2013; 112:2891-6.

Stowe RA, Mayer RP. Efficient screening of process variables. Ind Eng Chem, 1966; 56:36-40.

Ramasamy B, Nadarajah VD, Soong ZK, Lee HL, Mohammed SM. A preliminary study of the bioactivity of vegetative proteins extracted from Malasyian Bacillus thurinjigiensis isolates. Trop Biomed, 2008; 25:64-74.

Walia S, Sharma K, Ganguli S. Entomopathogenic nematodebacterium complex derived novel antibiotics and their pest control properties. In proceedings of short term National Training Course entitled "Advanced Techniques for Exploiting the ENBI Complexes (Entomopathogenic Nematodes-bacterial symbionts and the Insect hosts) for Biomanagement of Insect Pests of Crops, Indian Agricultural Research Institute, India, 2011.

Wang YH, Li YP, Zhang Q, Zhang X. Enhanced antibiotic activity of Xenorhabdus nematophila by medium optimization. Bioresour Technol, 2008; 99:1708-15.

Yang XF, Yang HW, Jian H, Liu Z. Effect of fermentation conditions on antibiotic production of Xenorhabdus nematophilus. Chin Microbial, 2001; 28:12-6.

How to cite this article:

Vani C, Jacob A, Christina Lydia J. Biocontrol potential of extracellular proteins from Xenorhabdus nematophilus on dengue vectors and the enhancement by response surface methodology. J App Pharm Sci, 2018; 8(11): 131-139. 